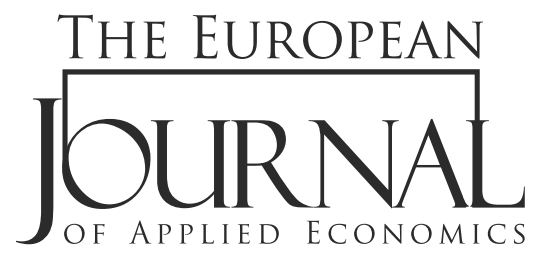

\title{
FORECASTING MODEL OF VIETNAMESE CONSUMERS' PURCHASE DECISION OF DOMESTIC APPAREL
}

\section{Dung Tien Luu*}

Lac Hong University, Viet Nam

Ho Phi Dinh, Phan Thiet University, Viet Nam

\section{Article info:}

Received: February 20, 2019

Correction: March 22, 2019

Accepted: April 6, 2019

\section{Keywords:}

consumer ethnocentrism, domestic apparel, perceived pric, perceived quality, Vietnam. 


\section{INTRODUCTION}

Vietnam's economy continues its deep international integration process with the continued signing of the Comprehensive and Progressive Partnership Trans-Pacific Partnership (CPTPP), the world's largest free-trade area with a combined market of 600 million people, and together with 16 signed linkage mechanism (1990-2016) promises to continue to increase growth opportunities for many economic sectors. At the same time, competitive pressure on the domestic market will also increase strongly in Vietnamese firms. The relaxation of trade policies has provided consumers with more foreign manufactured product choices than ever before. Consequently, their attitudes toward products originating from foreign countries have been of interest to domestic business and consumer behavior researchers for decades (Lu Wang \& Xiong Chen, 2004). Therefore, it is important to understand both the theoretical and practical aspects of the factors affecting the behavior of the Vietnamese consumer purchase decision.

Consumer behavior and consumer purchase behavior of domestic goods have received significant attention from researchers (Knight, 1999; Watson \& Wright, 2000; Vida \& Damjan, 2001; Lu Wang \& Xiong Chen, 2004; Nguyen, Nguyen \& Barrett, 2008; Dmitrovic, Vida, \& Reardon, 2009; Renko, Crnjak Karanović, \& Matić, 2012; Ha-Brookshire, 2012; Purwanto, 2014; He \& Wang, 2015; Asshidin, Abidin, \& Borhan, 2016; Mansi \& Pandey, 2016; Kacprzak \& Pawłowska, 2017; Puška et al., 2018). Previous studies used a microeconomic theory approach, the behavioral economics theory to explain consumers' domestic purchasing behavior and test for multiple product groups. However, there is no full research model in all cases, and many studies, rather than the use of dependent variables, are the real decisions of consumers made using other variables such as a willingness to buy or intention to purchase. Thus, the predictability power of these research models is not really significant.

The present study aims to determine factors affecting Vietnamese consumers' purchase decision of domestic apparel based on the binary logistic regression model. The structure of the article consists of five parts: i) Introduction, ii) Literature review, iii) Methodology, iv) Results and discussions, and v) Conclusions.

\section{LITERATURE REVIEW}

Kotler and Armstrong (2009) argue that consumers' decision-making processes were influenced by the factors including cultural, social, personal, and psychological. Consumer behavior patterns are used to describe the relationship between the three factors, including the stimulus, black box consciousness, and responses responding to consumer stimuli that affect purchasing decisions of consumers. The Theory of Reasoned Action (TRA) developed by Fishbein and Ajzen (1975) shows that the intention of an individual's behavior is influenced by two factors, including behavioral attitude, and subjective norm. These two factors directly affect the behavioral intent and then affect the actual behavior of an individual. The Theory of Planned Behavior (TPB) states that the intention of an individual is influenced by three factors: behavioral attitudes, subjective norms, and perceived behavior control. Perceived Behavioral Control (PBC) refers to the ease or difficulty of performing a behavior and whether or not the behavior is controlled (Ajzen, 1991). This extension involves explanations for when people intend to perform an activity that is impeded by their lack of confidence or lack of the right to conduct behavior (Ajzen, 1991). 
There are many previous kinds of research that have identified the factors that explain consumers' purchase behavior towards domestic goods. Key elements proposed in the previous studies include consumer ethnocentrism, perceived price, perceived quality, and demographic variables.

\section{Consumers ethnocentrism}

Ethnocentrism refers to the tendency of individuals to see their cultural group as proving the norms for acceptable behaviors and preferences. Highly ethnocentric individuals are intolerant and judgmental with respect to cultures different from their own (Luque-Martinez, Ibanez-Zapata, \& Barrio-Garcia, 2000). The tendency of consumers to be ethnocentric represents their beliefs about the appropriateness and moral legitimacy of purchasing foreign products (Shimp \& Sharma, 1987). Ethnocentric consumers prefer domestic goods because they believe that products from their own country are the best (Klein, Ettenson, \& Morris, 1998). Moreover, a concern for morality leads consumers to purchase domestic products, even though the quality is poorer than that of imports (Wall \& Heslop, 1986). Consumer ethnocentrism may play a significant role when people believe that their personal or national wellbeing is under threat from imports (Sharma, Shimp, \& Shin, 1995; Shimp \& Sharma, 1987). The more importance a consumer places on whether or not a product is made in his/her home country, the higher his/her ethnocentric tendency (Huddleston, Good, \& Stoel, 2001). Sharma, Shimp, and Shin (1995) show the effect of consumer preference leads to a preference for domestic goods, low prices for foreign goods and unwillingness to buy foreign goods while always favoring domestic goods. According to Netemeyer, Durvasula, and Lichtenstein (1991), the level of consumer preference indicates the degree of influence of buyers' beliefs, attitudes and behavior toward domestic products. In a study that examined the relationship between consumer ethnocentrism and evaluations of foreign-sourced products. Lantz and Loeb (1996) found that highly ethnocentric consumers have more favorable attitudes toward products from culturally similar countries. The higher the purchasing power, the higher the domestic buying behavior (Shimp \& Sharma, 1987; Watson \& Wright, 2000; Lu Wang \& Xiong Chen, 2004; Nguyen, Nguyen, \& Barrett, 2008; Zafer Erdogan \& Cevahir Uzkurt, 2010). In addition, individuals with high levels of consumer ethnocentrism would have more favorable attitudes toward products from culturally similar countries in comparison to products from culturally dissimilar countries, consumers' ethnocentric tendencies play a significant role in predicting purchase intentions towards domestically produced goods (Vida \& Damjan, 2001; Dmitrovic, Vida, \& Reardon, 2009; Renko, Crnjak Karanović, \& Matić, 2012; Purwanto, 2014; He \& Wang, 2015).

$H_{1}$ - Consumers' ethnocentrism has a positive impact on purchase decision of domestic apparel in Vietnam.

\section{Perceived price}

The price represents an extrinsic sign and provides one of the most important forms of information available to consumers when making a purchase decision (Jin \& Sternquist, 2003). Diehl, Kornish, and Lynch (2003) argue that consumers are price sensitive because they tend to look for lower-priced products and they want satisfaction through price comparisons between different products. Teas and Agarwal (2000) argue that the price offered was positively related to the perception of product quality and sacrificed by consumers. Zeithaml (1988) distinguished prices into two categories: objective price 
is the actual price of the product or service and price is perceived by the consumer. Price perception is a comparison between the actual objective price and the price at which consumers refer to, reflecting the buyer's subjective feelings or feelings about the price objective. On the consumer side, they often do not remember or know the actual price of the product, but instead feel the price suitability based on the perceived usefulness of the merchandise. This approach refers to the suitability of the price of the product or service that the user perceives. When consumers feel positive about price stability, and compare it to the usefulness they receive, they will shape their buying intentions and behavior (Ha-Brookshire, 2012; Winit \& Gregory, 2009; Prasad, 2014). Higher price is associated with higher likelihood of purchase (Sternquist, Byun, \& Jin, 2004).

$\mathrm{H}_{2}$ - The perceived price of domestic apparel has a positive influence on consumer purchase decision in Vietnam.

\section{Perceived quality}

Consumers' intention to purchase domestic products will be influenced by perceived quality. Perceived quality is a cognitive response to a product which influences product purchase (Kumar, Lee, \& Kim, 2009). In literature, quality perception is treated as a multi-dimensional concept, including appearance, color and design, durability, fashion, functionality, prestige, reliability, technical advancement, value for money, and workmanship (Darling \& Wood, 1990; Klein, Ettenson, \& Morris, 1998; Scott, Powers, \& Swan, 1997; Watson \& Wright, 2000). Thelen, Ford, and Honeycutt (2006) concluded that product characteristics may influence product preference for domestic versus imported more than consumer ethnocentrism levels. Consumers of the developing countries will go for non-local products because they are generally deemed to be of high quality (Khattak, Saeed, \& Shah, 2011). One of the ways in which consumers form perceptions about a brand is based upon the quality (Dooley \& Fryxell, 1999). A positive perception of quality is the source of the consumer's purchase decision (Aaker, 1991). Quality perception influences consumers' buying intentions (Dodds, Monroe, \& Grewal, 1991; Asshidin, Abidin, \& Borhan, 2016).

$H_{3}$ - The perceived quality of domestic apparel has a positive influence on consumer purchase decision in Vietnam.

\section{Demographic variables}

Demographic factors play an important role in the purchasing process. Age, level of education, occupation, number of household members, sex, marital status, and income are key demographic variables that influence consumer behavior (Iqbal Ghafoor \& Shahbaz, 2013; Alooma \& Lawan, 2013; Mazloumi et al., 2013; Sharma \& Kaur, 2015; Mansi \& Pandey, 2016; Kacprzak \& Pawłowska, 2017; Puška et al., 2018).

$\mathrm{H}_{4}$ - There is a significant relationship between demographic variables and consumer purchase decision of domestic apparel in Vietnam.

The logit model was estimated to explain and predict consumer's purchase decision of domestic products. The logit model was chosen for this study because of its mathematical simplicity and because of its asymptotic characteristics that constrain the predicted probabilities to a range between zero and one (Maddala, 1983). The maximum likelihood (ML) estimation procedure was used to obtain the model parameters. The 
model, selected to analyze the dependence of purchase decision $(\mathrm{Y})$ on the main factors, was specified as:

$\mathrm{Y}=\beta 1+\beta 2$ CONSUMER ETHNOCENTRISM $+\beta 3$ PERCEIVED QUALITY $+\beta 4$ PERCEIVED PRICE $+\beta 5$ AGE $+\beta 6$ FAMILY WITH CHILD + $\beta$ 7LEVEL OF EDUCATION + $\beta 8$ INCOME + $\beta 9$ SEX $+\mu$.

In which:

- Y: Purchasing decision.

- $\beta 1$ to $\beta$ 9: Regression coefficients of the independent variables (Consumer ethnocentrism, Perceived quality, Perceived price, Age, Family with child, Level of education, Income, and Sex, respectively.)

- $\mu$ : Residual (other factors not in the model).

\section{METHODOLOGY}

Binary Logistic Model was used to estimate parameters in the model. There are 14 items to measure Perceived price, Perceived quality, and Consumer ethnocentrism in the model (see Table 2). All items are measured by 5 -point Likert scales, which were 5 - strongly agree, 4 - agree, 3 - not sure, 2 - disagree and 1 - strongly disagree. We adopted previously validated measures with additional testing of reliability for indicator scale in this study.

The logit model is generally specified as follows:

$$
\operatorname{Ln}\left[\frac{p=1}{p=0}\right]=\beta_{0}+\beta_{1} X_{1}+\beta_{2} X_{2}+\ldots+\beta_{k} X_{i}(1)
$$

Where:

Ln: $\mathrm{Ln}$ is logarithm to the base of the mathematical constant $\mathrm{e}(\mathrm{e}=2.714)$.

$P(Y=1)=P 0$ : Probability of consumer purchase decision of domestic apparel.

$P(Y=0)=1$ - $P 0$ : Probability of consumers' non-purchasing decision of domestic apparel.

$X i$ : Independent variables.

$\beta$ is a scalar parameter to be estimated in equation (1).

Odds ratio $\left(O_{0}\right)$.

$$
O_{0}=\frac{P 0}{1-P 0}=\frac{P(\text { Puchaser })}{P(\text { Non_Purchaser })}
$$

Replace $\left(O_{0}\right)$ into the function (1):

$$
\operatorname{Ln} O_{0}=\beta_{0}+\beta_{1} X_{1}+\beta_{2} X_{2}+\ldots+\beta_{k} X_{i}(2)
$$

The logarithm of the Odds ratio is a linear function with independent variables Xi (Cox, 1970).

Agresti (2007) indicated the prediction function of the binary logit model: 
$E(Y / X i)=\frac{e^{(\text {LnOdds })}}{1+e^{(\text {LnOdds })}}$

$E(Y / X i):$ Probability of $Y=1$, when $\mathrm{X}$ equals Xi

LnOdds $=\beta 0+\beta 1 X 1+\beta 2 X 2+\ldots+\beta k X i$

According to Hair, Black, Babin, and Anderson (2010), the sample size used in the exploratory factor analysis was determined by the minimum $(\min =50)$ and the number of variables included in the model. The proportion of samples compared to an analytical variable was $5 / 1$ or $10 / 1$, which included 14 observations and therefore the sample size is at least $14^{\star} 5=70$ observations. Green (1991) suggested that in the regression model the minimum sample size was determined by the empirical formula $50+$ $8^{\star}$ independent variables in the model. This study has 08 independent variables so the sample size is at least $50+8^{\star} 8=114$ observations. Statistical analysis of the data obtained in this study was performed using the SPSS 22.0 software tool.

The sample for the study was drawn conveniently from 240 consumers in Ho Chi Minh city which represent different geographic, cultural, and commercial backgrounds of Vietnam. The stratified sampling plan was followed based on the population distribution in the districts of the city in order to ensure the representation of the research sample. Personal interviews were conducted at the large supermarkets by university students recruited from the city. The raw data set was publicly available at https://data.mendeley.com/datasets/dwj7hg3dt2/1

The research required that we examine a product category in which a domestic alternative was available. Apparel products were chosen as the domestic product category in this study.

The result of the survey showed that 121 cases (50.4 percent) purchased domestic apparel regularly while 119 cases (49.6 percent) did not. Demographic variables were described in Table 1.

\begin{tabular}{clcc}
\hline \multicolumn{2}{c}{ Demographic Variables } & Frequency & Percentage \\
\hline \multirow{2}{*}{ Sex } & 1. Male & 126 & $52.5 \%$ \\
& 0. Female & 114 & $47.5 \%$ \\
\hline \multirow{2}{*}{ Family with child } & 1. Yes & 150 & $62.5 \%$ \\
& 0. Others & 90 & $37.5 \%$ \\
\hline \multirow{2}{*}{ Level of education } & 1. High school or higher & 158 & $65.8 \%$ \\
& 0. Others & 82 & $34.2 \%$ \\
\hline \multirow{2}{*}{ Income/month: } & 1. 500 USD or higher & 67 & $27.9 \%$ \\
& 0. Less than 500 USD & 173 & $72.1 \%$ \\
\hline \multirow{3}{*}{ Willing to Pay for domestic prod- } & 1. $0 \%$ & 27 & $11.3 \%$ \\
ucts on imported products: & 2. Less than 5\% & 45 & $18.8 \%$ \\
& 4. $11-15 \%$ & 62 & $25.8 \%$ \\
& 5. $16-20 \%$ & 53 & $22.1 \%$ \\
& 6. Less than 20\% and more & 19 & $7.9 \%$ \\
\hline
\end{tabular}




\begin{tabular}{|c|c|c|c|}
\hline \multirow{5}{*}{ Consumption of domestic products: } & 1. None & 54 & $22.5 \%$ \\
\hline & 2. Less than $30 \mathrm{USD} /$ month & 71 & $29.6 \%$ \\
\hline & 2. 30-50 USD/ month & & \\
\hline & 3. More than $50 \mathrm{USD} /$ month & 52 & $21.7 \%$ \\
\hline & & 63 & $26.3 \%$ \\
\hline \multirow{2}{*}{ Purchasing decision $(\mathrm{Y})$} & $\begin{array}{l}\text { 1. regular buyers (buying domestic } \\
\text { apparel products sometimes, fre- } \\
\text { quently or always) }\end{array}$ & 121 & $50.4 \%$ \\
\hline & $\begin{array}{l}0 \text {. irregular buyers (never or rarely } \\
\text { buy domestic apparel products) }\end{array}$ & 119 & $49.6 \%$ \\
\hline
\end{tabular}

Table 1. Description of demographic variables

\section{RESULTS AND DISCUSSION}

\section{Reliability and Validity}

The reliability and validity of indicators in the model are tested by the system of criteria. As can be seen from Table 2 , the lowest Cronbach's alpha value is 0.712 , exceeding the cut value of 0.70 recommended (Hair, Black, Babin, \& Anderson, 2010). Convergent validity was estimated by factor loading. The value of Kaiser-Mayer-Olkin (KMO) was 0.833 (between 0.5 and 1.0) which means that data is significant for conducting a factor analysis. All loadings of variables are higher than the 0.50 (see Table 2). According to Hair, Black, Babin, and Anderson (2010), loadings \pm 0.50 or greater are considered practically significant.

\begin{tabular}{clc}
\hline Code & Items & \\
\hline & Perceived price; Cronbach's alpha $=0.712$ & Factor Loadings \\
\hline PP1 & $\begin{array}{l}\text { The price of domestic apparel is more acceptable than foreign manufac- } \\
\text { tured products. }\end{array}$ & 0.626 \\
\hline PP2 & Compared to the quality, the price of domestic apparel is cheaper. & 0.744 \\
\hline PP3 & $\begin{array}{l}\text { The amount of money to buy domestic apparel is perfectly suited to me } \\
\text { personally. }\end{array}$ & 0.793 \\
\hline PP4 & $\begin{array}{l}\text { The amount of money to buy domestic apparel compared with foreign manu- } \\
\text { factured products is reasonable. }\end{array}$ & 0.549 \\
\hline & Perceived quality; Cronbach's alpha 0.777 & 0.732 \\
\hline PQ1 & Seam strength is not inferior to foreign manufactured apparel. & 0.715 \\
\hline PQ2 & The fabric is not inferior to foreign manufactured apparel. & 0.741 \\
\hline PQ3 & Brand prestige is not inferior to foreign manufactured apparel. & 0.725 \\
\hline PQ4 & Production techniques are not inferior to foreign manufactured apparel. \\
\hline & Consumers ethnocentrism; Cronbach's alpha $=0.821$ & 0.648 \\
\hline CE1 & Foreign manufactured apparel products are a bad behavior of Vietnamese. & 0.654 \\
\hline CE2 & Vietnamese had better buy goods made in Vietnam. & 0.806 \\
\hline CE3 & $\begin{array}{l}\text { Buying foreign manufactured apparel is contributing to the loss of job among } \\
\text { Vietnamese workers. }\end{array}$ & 0.756 \\
\hline CE4 & Buying foreign manufactured apparel will help other countries get rich. & 0.768 \\
\hline CE5 & Foreign manufactured apparel cause harm to domestic firms. & 0.546 \\
\hline CE6 & $\begin{array}{l}\text { People should only buy foreign manufactured apparel when it cannot be } \\
\text { produced domestically. }\end{array}$ & \\
\hline
\end{tabular}

Table 2. Results of factor analysis and reliability tests. 


\section{Hypothesis Testing}

Table 3 shows maximum likelihood estimates of the binary logistic regression model, all of three estimated coefficients have expected signs and significance at the 10\%, 5\% level or higher level. The Nagelkerke R2 is 0.330 , an upper bound R2 for binary-choice models. The likelihood ratio test is significant at the 1-percent level, indicating the model has significant explanatory power.

\begin{tabular}{|c|c|c|c|c|c|}
\hline & Beta & Wald & Sig. & $\operatorname{Exp}(B)$ & $\begin{array}{l}\text { Change in Prob- } \\
\text { ability for signifi- } \\
\text { cant Coefficients } \\
(\mathrm{P} 0=10 \%)\end{array}$ \\
\hline Consumer ethnocentrism & 0.716 & 6.686 & .010 & 2.047 & 18.52 \\
\hline Perceived quality & 0.673 & 7.129 & .008 & 1.960 & 17.88 \\
\hline Perceived price & 0.791 & 10.794 & .001 & 2.205 & 19.68 \\
\hline Age & -0.073 & 5.771 & .016 & 0.930 & 9.37 \\
\hline Family with child & 0.802 & 6.311 & .012 & 2.229 & 19.85 \\
\hline Level of education & 1.513 & 18.941 & .000 & 4.540 & 33.53 \\
\hline Income & -0.906 & 6.877 & .009 & 0.404 & 4.30 \\
\hline Sex & -0.567 & 3.345 & .067 & 0.567 & 5.93 \\
\hline Constant & -6.217 & 13.428 & .000 & .002 & - \\
\hline \multicolumn{6}{|l|}{ Omnibus test } \\
\hline Chi-Square & 68.290 & & & & \\
\hline Significance & 0.000 & & & & \\
\hline Nagelkerke R Square & 0.330 & & & & \\
\hline Correct prediction & $75.8 \%$ & & & & \\
\hline
\end{tabular}

Table 3. Maximum Likelihood Estimates, Goodness-of-Fit Measures, and Change in Probability for significant Coefficients

The probabilities presented in Table 3 show the effects of changes in the individual explanatory variables on the likelihood of consumer purchase decision, assuming that all other explanatory variables are set to zero. The likelihood of the consumer purchase decision increases by 18.52 percent if consumers get one more unit in their ethnocentrism. The likelihood of the consumer purchase decision increases by 17.88 percent if consumers have one more unit in their perceived quality of domestic apparel. If consumers have one more unit in their perceived price of domestic apparel, there is a 19.68 percent increase in the likelihood of purchasing decision.

Among the demographic variables, the coefficients related to the families with a child, with a high school education or above, younger consumer, female consumer, and lower income have impacts on consumer purchase decision and are significant at the $10 \%, 5 \%$, and $1 \%$ level. Probabilistically, those families with a child were $19.85 \%$ more likely to buy domestic apparel regularly than others. Those with a high school education or higher were $33.53 \%$ more likely to buy domestic products regularly than were those with less than high school education. Similarly, those who are younger consumers, female consumers, and lower income consumers were $9.37 \%, 5.93 \%$, and $4.30 \%$ more likely to buy domestic apparel, respectively. Facing the context of Vietnam's extensive international integration, competition between domestic and foreign manufactured goods is fierce. Consumer purchase decisions for domestic products play an im- 
portant role in the competitiveness of domestic enterprises. This study suggests that the research model is quite adequate when assessing the impact of behavioral, psychological, and demographic factors on consumer purchase decision of domestic product. The research results contribute significantly to the current theoretical framework in clarifying consumer purchase behavior for domestic goods in one of the emerging markets. The research results are similar to the results of previous studies cited in the literature review of this article.

Based on the research results, the forecasting model of domestic apparel purchase by theVietnamese consumer could be shown as Table 4:

\begin{tabular}{clccc}
\hline Order & Variables & $\beta$ (beta) & \multicolumn{2}{c}{ Xi } \\
\cline { 3 - 5 } & & & Min & Max \\
\hline 1 & Consumer ethnocentrism & 0.716 & 1 & 5 \\
\hline 2 & Perceived quality & 0.673 & 1 & 5 \\
\hline 3 & Perceived price & 0.791 & 1 & 5 \\
\hline 4 & Age & -0.073 & 16 & 50 \\
\hline 5 & Family with child & 0.802 & 0 & 1 \\
\hline 6 & Level of education & 1.513 & 0 & 1 \\
\hline 7 & Income & -0.906 & 0 & 1 \\
\hline 8 & Sex & -0.567 & 0 & 1 \\
\hline 9 & Constant & -6.217 & - & 1.875 \\
\hline & & & -5.205 & 6.502 \\
\hline & LogOdds & 0.006 & 7.502 \\
\hline & $e^{\text {Logodds }}$ & & 1.006 & 86.67 \\
\hline
\end{tabular}

Table 4. Forecasting model of Vietnamese consumer purchase behavior of domestic apparel products

\section{CONCLUSIONS}

The study uses the Binary logistic econometric model to explain the factors affecting the Vietnamese consumer purchase decision of domestic apparel based on the data obtained from 240 consumers in Vietnam. The results show that consumer purchased decision was significant influences by i) the perception of price, ii) the perception of quality, iii) consumer ethnocentrism, and iv) demographic variables (age; families with a child; the level of education; income; and sex). This study provides valuable implications for business in the domestic market in the context of Vietnam's international integration. Domestic firms must recognize the significant relationship between consumers' perceived price, perceived quality of domestic products, consumer ethnocentrism, and their demographic variables with their purchase decision. Positive perceptions of quality and price are important for the long-term success of a brand. Therefore, it is recommended that domestic firms employ aggressive strategies to improve consumer perception of their brands in terms of quality and price appeal among those who have a higher interest in domestic products. 
This study has its limitations which can be resolved in future studies. Firstly, this study only conducted a product survey in one area of Vietnam, and therefore it is possible that the sample is not representative. In future studies, a wide range of products should be examined, and in more areas too, such as urban and rural ones. In addition, a comparison should be made with as many countries as possible so as to have more multidimensional assessments of consumers' domestic purchases; Secondly, this study uses the Binary Logistic model in accordance with the nature of the dependent variable. However, consumers' buying behavior also involves buying intentions, willingness to pay, satisfaction and loyalty after purchase. Therefore, further research should consider including these variables in the research model which are based on other quantitative models such as the structural equation model.

\section{REFERENCES}

Aaker, D. A (1991). Managing Brand Equity: Capitalizing on the Value of a Brand Name. New York: The Free Press. Agresti A. (2007). An introduction to Categorical Data Analysis. New York: A John Wiley \& Sons Publication.

Ajzen, I. (1991). The theory of planned behavior. Organizational Behavior and Human Decision Processes, 50 (2), 179-211.

Alooma, A.G., \& Lawan, L.A. (2013). Effects of Consumer Demographic Variables on Clothes Buying Behaviour in Borno State, Nigeria. International Journal of Basic and Applied Science, 1(4), 791-799.

Asshidin, N. H. N., Abidin, N., \& Borhan, H. B. (2016). Perceived quality and emotional value that influence consumer's purchase intention towards American and local products. Procedia Economics and Finance, 35, 639-643.

Cox, D. R. (1970). Analysis of Binary Data. London: Chapman and Hall.

Darling, J.R. \& Wood, V.R. (1990). A longitudinal study comparing perceptions of the US and Japanese consumer products in a third/neutral country: Finland 1975 to 1985. Journal of International Business Studies, 21(3), 427-50.

Diehl, K., Kornish, L. J., \& Lynch Jr, J. G. (2003). Smart agents: When lower search costs for quality information increase price sensitivity. Journal of Consumer Research, 30 (1), 56-71.

Dmitrovic, T., Vida, I., \& Reardon, J. (2009). Purchase behavior in favor of domestic products in the West Balkans. International Business Review, 18(5), 523-535.

Dodds, W.B., Monroe, K.B., \& Grewal, D. (1991). Effects of price, brand, and store information on buyers' product evaluations. Journal of Marketing Research, 28, 307-319.

Dooley, R.S. \& Fryxell, G.F. (1999). Attaining decision quality and commitment from the dissent: the moderating effects of loyalty and competence in strategic decision-making teams. Academy of Management Journal, $42(4), 389-402$.

Fishbein, M., \& Ajzen, I. (1975). Belief, attitude, intention, and behavior: An introduction to theory and research. Reading, Mass: Addison-Wesley.

Green, S. B. (1991). How many subjects does it take to do a regression analysis? Multivariate Behavioral Research, 26, 499-510.

Hair, J. F., Black, W. C., Babin, B. J., \& Anderson, R. E. (2010). Multivariate data analysis (7th Ed. Vol. 5). New York, Upper Saddle River: Pearson Prentice Hall.

Ha-Brookshire, J. E. (2012). Country of parts, country of manufacturing, and country of origin: consumer purchase preferences and the impact of perceived prices. Clothing and Textiles Research Journal, 30(1), 19-34.

He, J., \& Wang, C. L. (2015). Cultural identity and consumer ethnocentrism impacts on preference and purchase of domestic versus import brands: An empirical study in China. Journal of Business Research, 68(6), 1225-1233. 
Huddleston, P., Good, L.K. \& Stoel, L. (2001). Consumer ethnocentrism, product necessity and Polish consumers' perceptions of quality. International Journal of Retail \& Distribution Management, 29 (5), 236-46.

Iqbal, H.K., Ghafoor M.M., \& Shahbaz, S. (2013). Impact of Demographic Factors on Store Selection: An Insight in Pakistani Society. Journal of Marketing Management, 1(1), 34-45.

Jin, B., \& Sternquist, B. (2003). The influence of the retail environment on price perceptions: An exploratory study of US and Korean students. International Marketing Review, 20(6), 643-660.

Kacprzak, A., \& Pawłowska, A. (2017). Work and shopping overflow: Consequences and differentiation among selected psychological and demographic characteristics. European Management Journal, 35(6), 755-765.

Khattak, M. N., Saeed, M. M., \& Shah, T. A. (2011). Consumers' Attitudes Towards Non-Local Products: An Empirical Evidence from Pakistan”. Interdisciplinary Journal of Contemporary Research in Business, 3(2), 2039-2048.

Klein, J.G., Ettenson, R. \& Morris, M.D. (1998). The animosity model of foreign product purchase: an empirical test in the people's republic of China. Journal of Marketing, 62, 89-100.

Knight, G. A. (1999). Consumer preferences for foreign and domestic products. Journal of Consumer Marketing, $16(2), 151-162$.

Kumar, A., Lee, H. J., \& Kim, Y. K. (2009). Indian consumers' purchase intention toward the United States versus the local brand. Journal of business research, 62(5), 521-527.

Lantz, G. \& Loeb, S. (1996). Country of origin and ethnocentrism: an analysis of Canadian and American preferences using social identity theory. Advances in Consumer Research, 23, 374-388.

Luque-Martinez, T., Ibanez-Zapata, J. A., \& Barrio-Garcia, S. (2000). Consumer ethnocentrism measurementAn assessment of the reliability and validity of the CETSCALE in Spain. European Journal of Marketing, 34(11/12), 1353-1374.

Lu Wang, C., \& Xiong Chen, Z. (2004). Consumer ethnocentrism and willingness to buy domestic products in a developing country setting: testing moderating effects. Journal of Consumer Marketing, 21 (6), 391-400.

Maddala, G. S. (1983). Limited-dependent and qualitative variables in econometrics (No. 3). Cambridge University Press.

Mansi, M., \& Pandey, R. (2016). Impact of demographic characteristics of procurement professionals on sustainable procurement practices: Evidence from Australia. Journal of Purchasing and Supply Management, 22(1), 31-40.

Mazloumi, S.S.S., Efteghar, A., Ghalandari, A., Saifi, B., \& Aghandeh, I. (2013). Evaluating the effect of demographic differences on consumers' purchasing behavior (Case Study: Tetra Pak Consumers). International Research Journal of Applied and Basic Sciences, 4(7), 1866-1867.

Nguyen, Tho D, Nguyen Trang T.M, \& Nigel J. Barrett. (2008). Consumer ethnocentrism, cultural sensitivity, and intention to purchase local products evidence from Vietnam. Journal of Consumer Behavior, 88-100.

Netemeyer, R. G., Durvasula, S., \& Lichtenstein, D. R. (1991). A cross-national assessment of the reliability and validity of the CETSCALE. Journal of marketing research, 28 (3), 320-327.

Kotler, P. \& Armstrong, G. (2009). Principles of Marketing. Hanoi: Labor-Social Publication.

Prasad, G. H. S. (2014). Factors Influencing Buying Behavior of a Selected Apparel Retailer's Customers. Annual Research Journal of Symbiosis Centre for Management Studies, Pune, 1, 41-55.

Purwanto, E. (2014). The effect of consumer ethnocentrism on perceived domestic product quality and purchase intentions among young consumers in Jakarta, Indonesia. International Journal of Asian Social Science, 4(9), 1003-1012.

Puška, A., Stojanović, I., Šadić, S., \& Bečić, H. (2018). The influence of demographic characteristics of consumers on decisions to purchase technical products. The European Journal of Applied Economics, 15(2), 1-16.

Renko, N., Crnjak Karanović, B., \& Matić, M. (2012). Influence of consumer ethnocentrism on purchase intentions: Case of Croatia. Ekonomska misao i praksa, (2), 529-544. 
Scott, W.H., Powers, T.L. \& Swan, J.E. (1997). Modeling industrial buyer complaints: implications for satisfying and saving consumers. Journal of Marketing Theory and Practice, 5 (4), 12-22.

Sharma, S., Shimp, T. \& Shin, J. (1995). Consumer ethnocentrism: a test of antecedents and moderators. Journal of the Academy of Marketing Science, 23 (1), 26-37.

Shimp, T. A., \& Sharma, S. (1987). Consumer ethnocentrism: Construction and validation of the CETSCALE. Journal of marketing research, 280-289.

Sternquist, B., Byun, S. E., \& Jin, B. (2004). The dimensionality of price perceptions: a cross-cultural comparison of Asian consumers. The International Review of Retail, Distribution and Consumer Research, 14(1), 83-100.

Teas, R. K., \& Agarwal, S. (2000). The effects of extrinsic product cues on consumers' perceptions of quality, sacrifice, and value. Journal of the Academy of Marketing Science, 28(2), 278-290.

Thelen, S., Ford, J. B., \& Honeycutt Jr, E. D. (2006). Assessing Russian consumers' imported versus domestic product bias. Thunderbird International Business Review, 48(5), 687-704.

Vida, I., \& Damjan, J. (2001). The Role of Consumer Characteristics and Attitudes in Purchase Behavior of Domestic versus Foreign Made Products: The Case of Slovenia. Journal of East-West Business, 6(3), 111-133.

Wall, M. \& Heslop, sL.A. (1989). Consumer attitudes towards the quality of domestic and imported apparel and footwear. Journal of Consumer Studies and Home Economics, 13, 337-58.

Watson, J. J., \& Wright, K. (2000). Consumer ethnocentrism and attitudes toward domestic and foreign products. European Journal of Marketing, 34 (9/10), 1149-1166.

Winit, W., \& Gregory, G. (2009). Do Consumers Really Pay More for Their Own Country Brand? The Impact of Price and Ethnocentrism on Local Brand Preference. In Proceedings of ANZMAC Sustainable Management and Marketing Conference, (http://www. Duplication.net.au/ANZMAC09/papers/ANZMAC2009-534. pdf).

Zafer Erdogan, B., \& Uzkurt, C. (2010). Effects of the ethnocentric tendency on consumers' perception of product attitudes of foreign and domestic products. Cross-Cultural Management: An International Journal, 17 (4), 393-406.

Zeithaml, V. A. (1988). Consumer perceptions of price, quality, and value: a means-end model and synthesis of evidence. Journal of Marketing, 52 (3), 2-22. 


\section{MODEL PREDVIĐANJA DONOŠENJA ODLUKA KUPACA U VIJETNAMU PRILIKOM KUPOVINE ODEĆE DOMAĆE PROIZVODNJE}

\section{Rezime:}

Kako bi se podržale firme koje pripadaju domaćem tržištu, a teže postizanju konkurentnosti, u svetlu integracije Vijentama na međunarodnom planu, neophodna je analiza pokazatelja odluka kupaca prilikom kupovine domaćih proizvoda. Ovo istraživanje ima za cilj da utvrdi činioce koji utiču na odluke kupaca u Vijetnamu, u vezi sa kupovinom odeće domaće proizvodnje - a sama analiza zasnovana je na modelu binarne logističke regresije. $U$ istraživanju su upotrebljeni podaci koji ilustruju 240 kupaca u Vijetnamu, iz 2019. godine. Rezultati pokazuju da: i) utisak o ceni i) utisak o kvalitetu, iii) etnocentrizam kupca kao i iv) demografske varijable (starosna dob; deca u porodici; stepen obrazovanja; prihod i pol) značajno utiču na odluke kupaca $u$ Vijetnamu, u vezi sa kupovinom odeće domaće proizvodnje.
Ključne reči:

etnocentrizam kupca, odeća domaće proizvodnje, utisak o ceni, kvalitetu, Vijetnam 